\title{
Association of Shared Living Spaces and COVID-19 in University Students, Wisconsin, USA, 2020
}

John Paul Bigouette, Laura Ford, Hannah E. Segaloff, Kimberly Langolf, Juliana Kahrs, Tara Zochert, Jacqueline E. Tate, Douglas Gieryn, Hannah L. Kirking, Ryan P. Westergaard, Marie E. Killerby

We describe characteristics associated with having coronavirus disease (COVID-19) among students residing on a university campus. Of 2,187 students, 528 (24.1\%) received a COVID-19 diagnosis during fall semester 2020. Students sharing a bedroom or suite had approximately twice the odds of contracting COVID-19 as those living alone.

Tn 2020, multiple outbreaks of coronavirus disease (COVID-19), the disease caused by infection with severe acute respiratory syndrome coronavirus 2 (SARS$\mathrm{CoV}-2$ ), were documented in institutions of higher education (IHEs; e.g., colleges and universities) across the United States (1-5). Before students returned to campus, IHEs implemented measures to reduce the spread of SARS-CoV-2 on campus (6-8). The congregate nature of on-campus residence halls might increase the odds of contracting SARS-CoV-2 because of closecontact exposure, but the association has not been well studied. We describe characteristics of on-campus students associated with having a SARS-CoV-2 infection, including if they shared living spaces, during the fall semester at a Wisconsin, USA, university.

\section{The Study}

The Centers for Disease Control and Prevention (CDC) partnered with the Wisconsin Division of Health Services (WDHS; Madison, WI, USA) and University of Wisconsin-Oshkosh to investigate COVID-19 among on-campus residents during the fall 2020 semester

Author affiliations: Centers for Disease Control and Prevention, Atlanta, Georgia, USA (J.P. Bigouette, L. Ford, H.E. Segaloff, J.E. Tate, H.L. Kirking, M.E. Killerby); Wisconsin Department of Health Services, Madison, Wisconsin, USA (H.E. Segaloff, R.P. Westergaard); University of Wisconsin-Oshkosh, Oshkosh, Wisconsin, USA (K. Langolf, J. Kahrs, T. Zochert); Winnebago County Health Department, Oshkosh (D. Gieryn)
(September 2-December 19). On-campus residents were housed in 8 dormitories (dorms A-H). In 7 dormitories, students resided in double-occupancy rooms (dorm C included 4 triple-occupancy rooms) and shared bathrooms along with a common area per floor. Dorm D was the only dormitory made up of suites in which $\leq 4$ students lived in either 4 single-occupancy or 2 doubleoccupancy bedrooms with the suite's own bathroom, common area, and kitchen. Not all bedrooms were occupied at their full capacity. After a positive COVID-19 diagnosis, on-campus residents were housed in an isolation dormitory. Students who might have been exposed were housed in a separate quarantine dormitory $(9,10)$. (Appendix, https://wwwnc.cdc.gov/EID/ article/27/11/21-1000-App1.pdf).

Data provided by the university included the number of available rooms, dormitory room types, student housing contracts, serial testing records, and a list of all student COVID-19 cases. For our study, we defined students sharing a bedroom with another student at the start of the semester as having a shared bedroom. Students sharing a suite or defined as having a shared bedroom were classified as having a shared living space. In addition, we defined dormitory floorlevel occupancy as the number of occupied rooms divided by the number of rooms per floor. We defined a laboratory-confirmed case as a positive SARS-CoV-2 antigen or reverse transcription PCR test result for any on-campus student during the fall semester (11).

All data were analyzed using $\mathrm{R}$ version 4.0.2 (R Foundation for Statistical Computing, https:// www.r-project.org). We used $\chi^{2}$ tests, Fisher exact tests, and $\mathrm{t}$-tests to determine differences between COVID-19 cases and noncases. We modeled the association between student characteristics and a laboratory-confirmed COVID-19 case using univariable and multivariable logistic regression; covariates were age, sex, race, ethnicity, all dormitories, and dormitory floor level occupancy. The dormitory with the 
Table 1. Demographics of on-campus university students in study of coronavirus disease transmission, Wisconsin, USA, September 2-December 19, 2020

\begin{tabular}{|c|c|c|c|c|}
\hline Characteristic & Overall & COVID-19 cases $^{*}$ & Non-COVID-19 cases & p value \\
\hline Total no. persons & 2,187 & 528 & 1,659 & \\
\hline Age, y, mean (SD) & $19.3(1.1)$ & $19.3(1.2)$ & $19.2(0.9)$ & $<0.001$ \\
\hline \multicolumn{5}{|l|}{ Sex, no. (\%) } \\
\hline $\mathrm{F}$ & $1,326(60.6)$ & $324(61.3)$ & $1,002(60.4)$ & 0.641 \\
\hline M & $820(37.5)$ & $192(36.4)$ & $628(37.8)$ & \\
\hline Unknown & $41(1.9)$ & $12(2.3)$ & $29(1.8)$ & \\
\hline \multicolumn{4}{|l|}{ Race, no. (\%) } & 0.017 \\
\hline Alaska Native or Native American & $13(0.6)$ & $5(0.9)$ & $8(0.5)$ & \\
\hline Asian & $86(3.9)$ & $13(2.5)$ & $73(4.4)$ & \\
\hline Black or African American & $99(4.5)$ & $20(3.8)$ & $79(4.8)$ & \\
\hline Native Hawaiian or other Pacific Islander & $33(1.5)$ & $1(0.2)$ & 32 (1.9) & \\
\hline White & $1,737(79.4)$ & $434(82.2)$ & $1,303(78.5)$ & \\
\hline Other & $23(1.1)$ & $2(0.4)$ & $21(1.3)$ & \\
\hline Unknown/declined & $196(9.0)$ & $53(10.0)$ & $143(8.6)$ & \\
\hline \multicolumn{4}{|l|}{ Ethnicity, no. (\%) } & 0.014 \\
\hline Hispanic or Latino & $127(5.8)$ & $17(3.2)$ & $110(6.6)$ & \\
\hline Not Hispanic or Latino & $1,744(79.7)$ & $431(81.6)$ & $1,313(79.2)$ & \\
\hline Unknown/declined & $316(14.5)$ & $80(15.2)$ & $236(14.2)$ & \\
\hline \multicolumn{4}{|l|}{ Dormitory, no. (\%) } & $<0.001$ \\
\hline Dorm A & $176(8.1)$ & $33(6.2)$ & $143(8.6)$ & \\
\hline Dorm B† & $206(9.4)$ & $40(7.6)$ & $166(10.0)$ & \\
\hline Dorm C & $313(14.3)$ & $78(14.8)$ & $235(14.2)$ & \\
\hline Dorm D‡ & 269 (12.3) & $83(15.7)$ & $186(11.2)$ & \\
\hline Dorm E & $264(12.1)$ & $45(8.5)$ & $219(13.2)$ & \\
\hline Dorm F† & $405(18.5)$ & $126(23.9)$ & $279(16.8)$ & \\
\hline Dorm G† & $204(9.3)$ & $53(10.0)$ & $151(9.1)$ & \\
\hline Dorm H & $350(16.0)$ & $70(13.3)$ & $280(16.9)$ & \\
\hline \multicolumn{4}{|l|}{ Shared bedroom, no. (\%)§ } & 0.001 \\
\hline Yes & $1,630(74.5)$ & $423(80.1)$ & 1,207 (72.8) & \\
\hline No & $557(25.5)$ & $105(19.9)$ & $452(27.2)$ & \\
\hline \multicolumn{4}{|l|}{ Shared living space, no. (\%)† } & $<0.001$ \\
\hline Yes & $1,787(81.7)$ & $472(89.4)$ & $1,315(79.3)$ & \\
\hline No & $400(18.3)$ & $56(10.6)$ & $344(20.7)$ & \\
\hline \multicolumn{5}{|c|}{$\begin{array}{l}\text { *A laboratory-confirmed case was defined as a positive SARS-CoV-2 antigen or reverse transcription PCR test result for any on-campus student during } \\
\text { the fall semester. } \\
\text { †First-year student dormitories. } \\
\text { †Only suite-style dormitory made up of suites where } \leq 4 \text { students were housed in either } 4 \text { single-occupancy or } 2 \text { double-occupancy bedrooms with the } \\
\text { suite's own bathroom, common area, and kitchen. } \\
\S S t u d e n t s \text { who share a bedroom with }>1 \text { students. }\end{array}$} \\
\hline
\end{tabular}

Table 2. Characteristics of living situations for on-campus students at a university in study of coronavirus disease transmission, Wisconsin, USA, September 2-December 19, 2020

\begin{tabular}{|c|c|c|c|c|c|c|c|c|c|}
\hline \multirow[b]{2}{*}{ Characteristic } & \multicolumn{9}{|c|}{ Dormitory* } \\
\hline & A & $\mathrm{B} \dagger$ & $\mathrm{C}$ & $\mathrm{D \ddagger}$ & $E$ & $\mathrm{~F} \dagger$ & $\mathrm{G \dagger}$ & $\mathrm{H}$ & Overall \\
\hline Suite-style dormitory $\ddagger$ & No & No & No & Yes & No & No & No & No & NA \\
\hline No. occupied floors & 4 & 4 & 4 & 5 & 7 & 8 & 4 & 4 & 40 \\
\hline No. rooms & 122 & 120 & 234 & 264 & 259 & 240 & 115 & 253 & 1,607 \\
\hline No. occupied bedrooms & 107 & 110 & 202 & 216 & 186 & 218 & 108 & 223 & 1,307 \\
\hline Overall dormitory occupancy rate, \% & 87.7 & 91.7 & 86.3 & 81.8 & 71.8 & 90.8 & 93.9 & 88.1 & 81.3 \\
\hline Dormitory floor occupancy rate,§ mean \% (SD) & $\begin{array}{l}87.7 \\
(0.5)\end{array}$ & $\begin{array}{c}90.1 \\
(15.9)\end{array}$ & $\begin{array}{l}86.3 \\
(6.0)\end{array}$ & $\begin{array}{l}82.1 \\
(6.7)\end{array}$ & $\begin{array}{c}72.2 \\
(14.9)\end{array}$ & $\begin{array}{l}86.8 \\
(9.3)\end{array}$ & $\begin{array}{l}89.9 \\
(7.7)\end{array}$ & $\begin{array}{l}88.1 \\
(2.9)\end{array}$ & $\begin{array}{l}85.4 \\
(8.0)\end{array}$ \\
\hline No. student & 176 & 206 & 313 & 269 & 264 & 405 & 204 & 350 & 2,187 \\
\hline Students per dormitory floor, mean (SD) & $\begin{array}{l}44.0 \\
(6.6)\end{array}$ & $\begin{array}{l}51.5 \\
(15.2)\end{array}$ & $\begin{array}{c}78.3 \\
(14.1)\end{array}$ & $\begin{array}{l}53.8 \\
(5.9)\end{array}$ & $\begin{array}{c}37.7 \\
(10.6)\end{array}$ & $\begin{array}{c}50.6 \\
(12.0)\end{array}$ & $\begin{array}{c}51.0 \\
(12.7)\end{array}$ & $\begin{array}{c}87.5 \\
(14.8)\end{array}$ & $\begin{array}{l}54.7 \\
(11.5)\end{array}$ \\
\hline $\begin{array}{l}\text { No. COVID-19 casesI } \\
\% \text { Students positive }\end{array}$ & $\begin{array}{c}33 \\
18.8\end{array}$ & $\begin{array}{c}40 \\
19.4\end{array}$ & $\begin{array}{c}78 \\
24.9\end{array}$ & $\begin{array}{c}83 \\
30.9\end{array}$ & $\begin{array}{c}45 \\
17.0\end{array}$ & $\begin{array}{l}126 \\
31.1\end{array}$ & $\begin{array}{c}53 \\
26.0\end{array}$ & $\begin{array}{c}70 \\
20.0\end{array}$ & $\begin{array}{l}528 \\
24.1\end{array}$ \\
\hline $\begin{array}{l}\text { "Each dormitory floor had a shared common space } \\
\text { †First-year student dormitories. } \\
\text { fOnly suite-style dormitory comprised of suites wher } \\
\text { bathroom, common area, and kitchen. } \\
\text { §Dormitory floor-level occupancy was defined as the } \\
\text { TA laboratory-confirmed case was defined as a posi }\end{array}$ & athroom & xcept d & D. & 60.0 & 11.0 & 41.1 & dron & th th & s own \\
\hline
\end{tabular}


lowest COVID-19 positivity for the semester was the reference group. Sharing a bedroom or living space were analyzed in separate models. We conducted our investigation consistent with applicable federal laws and CDC policy (e.g., 45 C.F.R. part 46.102(l)(2), 21 C.F.R. part 56; 42 U.S.C. §241(d); 5 U.S.C. 145 §552a; 44 U.S.C. $\$ 3501$ et seq.). CDC and WDHS reviewed the investigation; in addition, the university's ethics review board determined the activities to be nonresearch public health surveillance.

At the start of the fall semester, 2,187 students had on-campus housing contracts. The median age of on-campus students was 19 years; $60.5 \%$ were female,
79.4\% White, and 79.7\% non-Hispanic/Latino (Table 1). Dormitory student populations range was 176-405 students per dormitory, with a mean of 55 students per occupied dormitory floor and a mean floor occupancy of $85 \%$ (Table 2) at semester start. Overall, $74.5 \%$ of students shared a bedroom and $81.7 \%$ of students shared a living space.

During the semester, 528 (24.1\%) COVID-19 cases were identified among on-campus students. The percentage of students diagnosed with COVID-19 was $17.0 \%-31.1 \%$ across dormitories for the fall semester; the lowest percent positivity was in dorm E. All dormitories saw a rise in cases in mid- to late September (Figure 1).

A

...... Weekly testing requirement

B
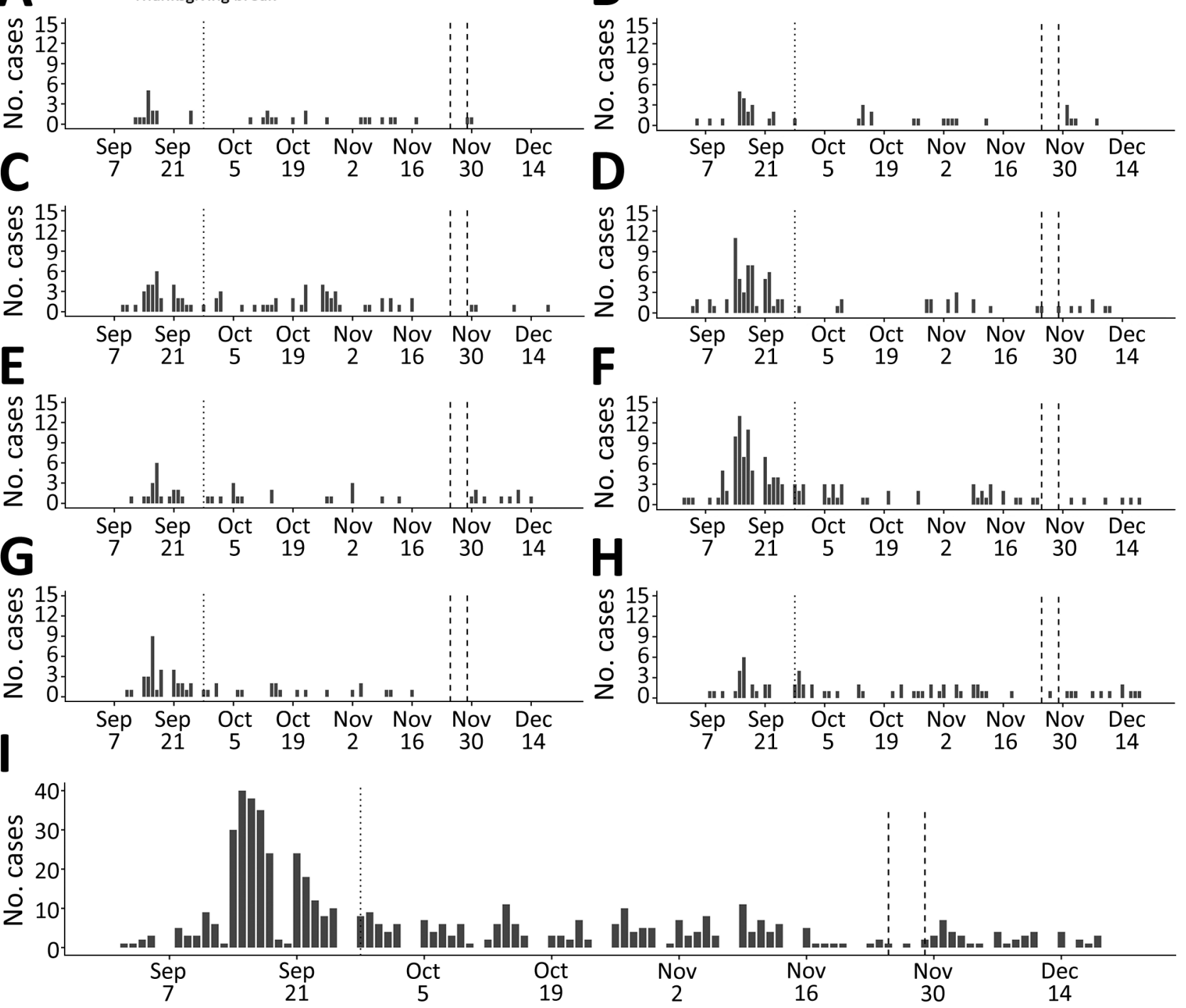

Figure 1. Epidemic curves of daily coronavirus disease cases in each of 8 dormitories (A-H) and overall (I) for a total of 528 cases at a university in Wisconsin, USA, September 2-December 19, 2020. Vertical dotted lines indicate the change in testing requirement from biweekly to weekly. On-campus students returning after the Thanksgiving break (November 25-29, 2020; vertical dashed lines) were required to test before leaving campus and twice $>48$ hours apart upon returning to campus. Dorms A, B, F, and G house first-year students. Dorm D is made up of suites of 4 single- or 2 double-occupancy bedrooms with a shared bathroom, common area, and kitchen. 


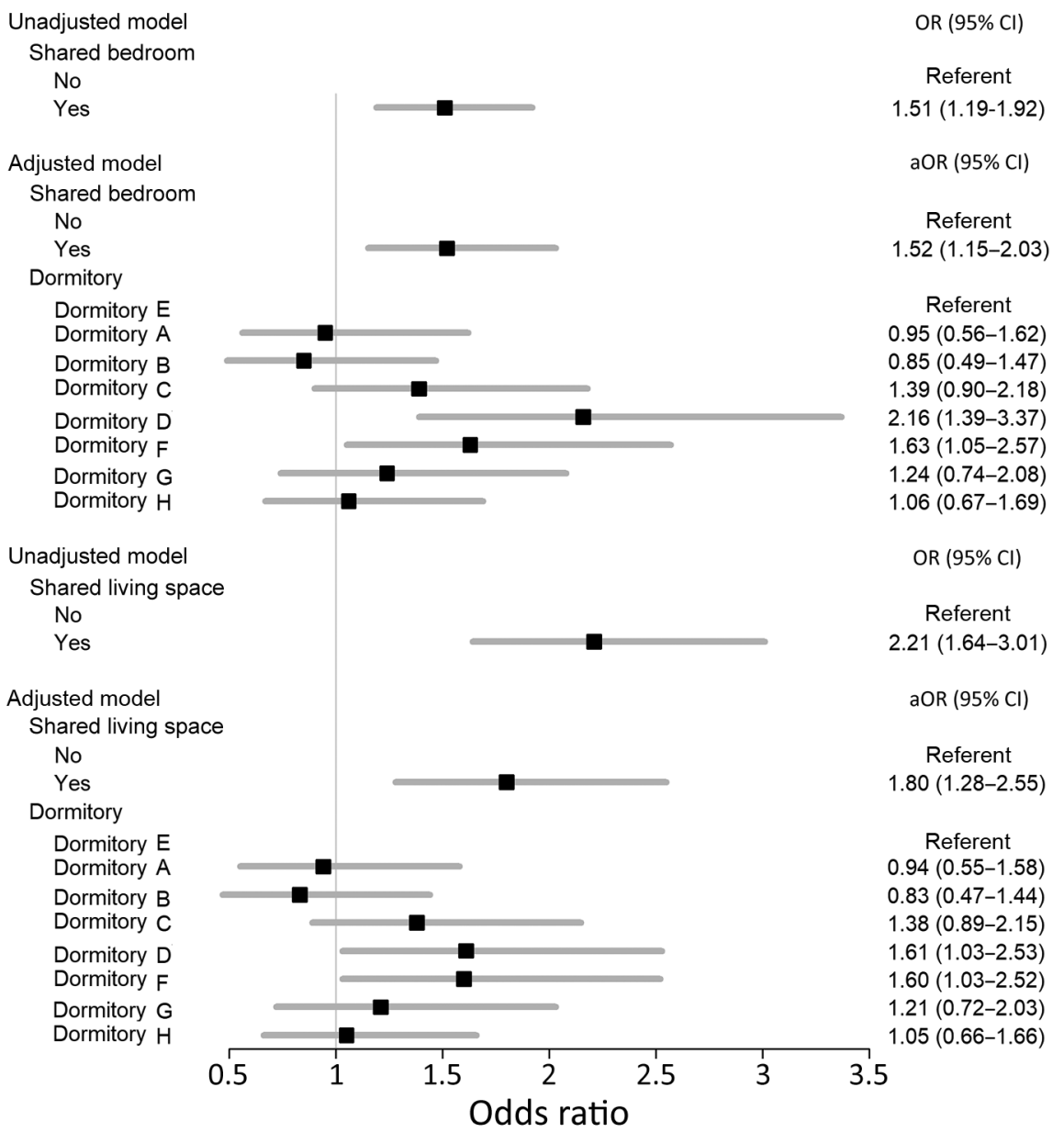

Figure 2. Associations between shared living spaces and coronavirus disease (COVID-19) at a university $(\mathrm{N}=2,187)$, Wisconsin, USA, September 2-December 19, 2020. Black boxes indicate odds ratios; gray bars indicate $95 \% \mathrm{Cls}$. Models were adjusted for age, sex, race, ethnicity, dormitories, and floor level occupancy (\%). Shared living space was defined as one in which $>2$ students share either a bedroom or suite. Dorms A, B, F, and $G$ housed first-year students. Dorm E was selected as the reference group because it had the lowest semester COVID-19 positivity among on-campus residents. Dorm $D$ is composed of suites of 4 singleoccupancy or 2 double-occupancy bedrooms with a shared bathroom, common area, and kitchen. aOR, adjusted odds ratio; OR, odds ratio.
Using a univariable regression model, we found that students who shared a bedroom had 1.52 (95\% CI 1.19-1.92) times the odds of receiving a COVID-19 diagnosis as students who lived alone (Figure 2). The effect estimate remained unchanged in the adjusted multivariable regression model (Appendix Table 1). However, in the adjusted model, students with a shared living space (e.g., suites and bedrooms) had 1.80 (95\% CI 1.28-2.55) times the odds of testing positive for COVID-19 compared with students living alone. After controlling for shared living status, students from 2 dormitories, dorms D and F, had higher odds for COVID-19 than dorm E students in both models.

CDC has provided guidance on prevention measures to reduce the transmission of SARS-CoV-2 at IHEs $(6,8)$. Similar to other IHE outbreak reports from the United States, the university saw a surge in cases during September (1,3-5). After the surge, the university updated their COVID-19 prevention plan such that residential students were tested weekly instead of biweekly for SARS-CoV-2, messaging on COVID-19 prevention measures increased, and on-campus dining was limited to takeout only for 2 weeks.

\section{Conclusions}

Despite this university's updated COVID-19 prevention plan, students sharing a suite or bedroom had higher odds of being diagnosed with COVID-19. SARS-CoV-2 household transmission studies have shown that households are a significant transmission source for both symptomatic and asymptomatic persons $(12,13)$. For example, a meta-analysis found that the household SARS-CoV-2 secondary attack rate was $16.6 \%(8,12)$. Reducing the number of students with roommates or those in suite-style units is needed to limit SARS-CoV-2 transmission.

After adjusting for sharing bedrooms or living spaces, students from 2 dormitories still had higher odds of having COVID-19 than students from the dormitory with the lowest percentage of positive students. This finding could be associated with differing student attitudes and social behaviors towards COVID-19 (14). 
Racial and ethnic disparities in COVID-19 incidence have been found in persons $<25$ years of age in the United States (15). However, we found that Native Hawaiian or other Pacific Islander students had lower odds of having COVID-19 compared with White students, and Hispanic students had lower odds than non-Hispanic students: adjusted odds ratio for Native Hawaiian or other Pacific Islander students was 0.13 (95\% CI 0.01-0.63) and for Hispanic students it was 0.56 (95\% CI 0.31-0.96). We observed no other associations by age, sex, race category, and dormitory floor occupancy. These results should be interpreted with caution; our findings could be the result of low sample sizes in some groups or residual confounding.

The first limitation of our study is that findings from this IHE may not be generalizable for all IHEs. Second, these results characterize an association between sharing a living space and COVID-19 and do not necessarily indicate roommate transmission. Third, students may have moved out of the dormitory during the semester, causing an underestimation of attack rates and misclassification of those students with roommates or suitemates for the term. Last, because this investigation was cross-sectional in design, a causal relationship cannot be determined.

In summary, sharing a living space or bedroom was associated with increased odds of having COVID-19 even with COVID-19 prevention policies at a Wisconsin university. Reducing the number of students sharing living spaces could further prevent the spread of SARS-CoV-2 on-campus as part of COVID-19 prevention practices at IHEs.

\section{About the Author}

Dr. Bigouette is an Epidemic Intelligence Service Officer in the Polio Eradication Branch, Global Immunization Division, Center for Global Health, Centers for Disease Control and Prevention. His primary research interests include infectious disease and disaster epidemiology, emergency management and response, and vaccinepreventable disease work.

\section{References}

1. Fox MD, Bailey DC, Seamon MD, Miranda ML. Response to a COVID-19 outbreak on a university campus - Indiana, August 2020. MMWR Morb Mortal Wkly Rep. 2021;70:11822. https://doi.org/10.15585/mmwr.mm7004a3

2. Pray IW, Kocharian A, Mason J, Westergaard R, Meiman J. Trends in outbreak-associated cases of COVID-19Wisconsin, March-November 2020. MMWR Morb Mortal Wkly Rep. 2021;70:114-7. https://doi.org/10.15585/ mmwr.mm7004a2

3. Vang KE, Krow-Lucal ER, James AE, Cima MJ, Kothari A, Zohoori N, et al. Participation in fraternity and sorority activities and the spread of COVID-19 among residential university communities - Arkansas, August 21-September 5, 2020. MMWR Morb Mortal Wkly Rep. 2021;70:20-3. https://doi.org/10.15585/mmwr.mm7001a5

4. Wilson E, Donovan CV, Campbell M, Chai T, Pittman K, Seña AC, et al. Multiple COVID-19 clusters on a university campus - North Carolina, August 2020. MMWR Morb Mortal Wkly Rep. 2020;69:1416-8. https://doi.org/10.15585/ mmwr.mm6939e3

5. Leidner AJ, Barry V, Bowen VB, Silver R, Musial T, Kang GJ, et al. Opening of large institutions of higher education and county-level COVID-19 incidence-United States, July 6-September 17, 2020. MMWR Morb Mortal Wkly Rep. 2021;70:14-9. https://doi.org/10.15585/ mmwr.mm7001a4

6. Centers for Disease Control and Prevention. Coronavirus disease 2019 (COVID-19): testing, screening, and outbreak response for institutions of higher education (IHEs). 2020 [cited 2021 Feb 20]. https:/ / www.cdc.gov/coronavirus/2019ncov/community/colleges-universities/ihe-testing.html

7. Walke HT, Honein MA, Redfield RR. Preventing and responding to COVID-19 on college campuses. JAMA. 2020;324:1727-8. https://doi.org/10.1001/jama.2020.20027

8. Centers for Disease Control and Prevention. Coronavirus disease 2019 (COVID-19): considerations for institutions of higher education. 2020 [cited 2021 Feb 23]. https:/ / www.cdc. gov/coronavirus/2019-ncov/community/collegesuniversities/considerations.html

9. Centers for Disease Control and Prevention. Coronavirus disease 2019 (COVID-19): when to quarantine. 2021 [cited 23 Feb 2021]. https:/ / www.cdc.gov/coronavirus/2019-ncov/ if-you-are-sick/quarantine.html

10. Centers for Disease Control and Prevention. Coronavirus disease 2019 (COVID-19): isolate if you are sick. 2021 [cited 2021 Feb 22]. https:/ / www.cdc.gov/ coronavirus/ 2019-ncov/if-you-are-sick/isolation.html

11. Council of State and Territorial Epidemiologists. Coronavirus disease 2019 (COVID-19) 2020 interim case definition. 2020 [cited 2021 Feb 23]. https:/ / wwwn.cdc.gov/ nndss/conditions/coronavirus-disease-2019-covid-19/ case-definition/2020/08/05/

12. Madewell ZJ, Yang Y, Longini IM, Jr, Halloran ME, Dean NE. Household transmission of SARS-CoV-2: a systematic review and meta-analysis. JAMA Network Open. 2020;3:e2031756. https://doi.org/10.1001/jamanetworkopen.2020.31756

13. Grijalva CG, Rolfes MA, Zhu Y, McLean HQ, Hanson KE, Belongia EA, et al. Transmission of SARS-COV-2 infections in households - Tennessee and Wisconsin, AprilSeptember 2020. MMWR Morb Mortal Wkly Rep. 2020;69:1631-4. https:/ / doi.org/10.15585/mmwr.mm6944e1

14. Cohen AK, Hoyt LT, Dull B. A descriptive study of COVID-19-related experiences and perspectives of a national sample of college students in spring 2020. J Adolesc Health. 2020;67:369-75. https://doi.org/10.1016/ j.jadohealth.2020.06.009

15. Van Dyke ME, Mendoza MCB, Li W, Parker EM, Belay B, Davis EM, et al. Racial and ethnic disparities in COVID-19 incidence by age, sex, and period among persons aged $<25$ years - 16 US jurisdictions, January 1-December 31, 2020. MMWR Morb Mortal Wkly Rep. 2021;70:382-388. http://dx.doi.org/10.15585/mmwr.mm7011e1

Address for correspondence: John Paul Bigouette, Centers for Disease Control and Prevention, 1600 Clifton Rd NE, Mailstop H24-2, Atlanta, GA 30329-4027, USA; email: JBigouette@cdc.gov 